WARSZTATY Z GEOGRAFII TURYZMU

ISBN 978-83-7525-713-7 s. 49-66

http:/dx.doi.org/10.18778/7525-713-7.04

Marta DEREK

Uniwersytet Warszawski

\title{
PRZESTRZEŃ CZASU WOLNEGO W OBIEKTACH POPRZEMYSŁOWYCH NA WARSZAWSKIEJ PRADZE POMYSŁ NA SUKCES?
}

Jeszcze do połowy lat 70. XX w. w miastach na terenach, z których przemysł przenoszony był na przedmieścia lub do specjalnych stref przemysłowych, powstawały biurowce albo bloki mieszkalne (TOMAS 1982). Obszary poprzemysłowe były wyburzane lub przebudowywane, nie wydawały się interesujące ani do ponownego wykorzystania, ani (tym bardziej) nie stanowiły żadnej miejskiej atrakcji. Tendencja ta zaczęła się zmieniać od początku lat 80. XX w., kiedy wiele krajów Europy Zachodniej zaczęło interesować się swoim dziedzictwem przemysłowym. Proces ten rozpoczął się w Wielkiej Brytanii - kolebce przemysłu (zob. JANSEN-VERBEKE 1999, URRY 2007, DEREK 2010a), jednak w dosyć krótkim czasie także inne kraje zaczęły dostrzegać problemy, ale i potencjał tych obszarów.

Ponadto, jak zauważa GRAVARI-BARBAS (2004, s. 280): „po latach rozlewania miasta i budowania na terenach dziewiczych zdajemy sobie dziś sprawę z tego, że duża część miejsc w XXI w. będzie budowana na terenach «z odzysku» (recyclés), związanych wcześniej z uprzemysłowieniem. Główne kierunki myślenia o współczesnym mieście ewoluują $\mathrm{w}$ stronę miejskiej odnowy i dotyczą sposobu, w jaki przestrzenie obecnie porzucone i nieużytkowane staną się ponownie użytkowane, zainwestowane i zintegrowane $\mathrm{z}$ miastem". 
To właśnie na terenach miejskich obszary poprzemysłowe są szczególnie ważnym problemem. Jak pisze ZAŁUSKI (2005), opuszczone tereny bardzo szybko zaczynają oddziaływać negatywnie na obszary sąsiednie, a podstawowym problemem jest degradacja krajobrazu miejskiego. Ponadto obiekty przemysłowe są zazwyczaj silnymi dominantami przestrzennymi, często głównymi elementami kompozycji określającymi tożsamość miasta. Niejednokrotnie zajmują centralne, najbardziej atrakcyjne fragmenty miast, a zatem uwolnienie tych terenów jest szansą rozwoju dla zatłoczonych i przeinwestowanych obszarów śródmiejskich. Biorąc powyższe pod uwagę, jak również doceniając wartości historyczne i estetyczne architektury przemysłowej, na dawne obszary przemysłowe (ale także pokolejowe, powojskowe czy poportowe, wspólnie określane mianem miejskich nieużytków lub miejskich ugorów ang. brownfield, fr. friche urbaine) coraz częściej zaczęto wprowadzać nowe funkcje; najczęściej handlowe, mieszkaniowe, biurowe, usługowe, kulturalne i turystyczne. $W$ efekcie rewitalizacja obszarów zdegradowanych stała się $\mathrm{w}$ ostatnich dekadach XX w. jedną z głównych tendencji urbanistycznych, a przedsięwzięcia, takie jak te, które zrealizowano w Manchesterze, Bilbao czy Zagłębiu Ruhry, są przykładami spektakularnego ponownego rozwoju obszarów miejskich. Stały się one także ważnymi atrakcjami turystycznymi.

\section{Przestrzeń czasu wolnego w obiektach poprzemysłowych...}

Jednym z pomysłów na ponowne wykorzystywanie obszarów poprzemysłowych było wprowadzanie tam funkcji związanych $\mathrm{z}$ zagospodarowaniem czasu wolnego. Pierwszą $z$ nich była funkcja kulturalna, która zaczęła pojawiać się na takich nieużytkowanych terenach spontanicznie już w latach 70. XX w. za sprawą różnych oddolnych inicjatyw nieformalnych, a częstokroć wręcz nielegalnych. Młodzi, początkujący, awangardowi artyści zajmowali porzucone i zaniedbane budynki, tworząc tam swoje miejsca do pracy (tzw. squaty, jeśli były one nielegalne). Były one dla nich atrakcyjne ze względu na bardzo niskie (jeśli w ogóle) czynsze oraz ogromne możliwości dla działań artystycznych - jak podaje F. Raffin (2000, cyt. za: GRAVARI-BARBAS 2004), działania artystyczne mają często takie same potrzeby jak produkcja przemysłowa: potrzebują przestrzeni, są hałaśliwe, a także wymagają używania surowych i brudnych materiałów. Pierwsze takie kulturalno-alternatywne doświadczenia na terenach poprzemysłowych miały miejsce w Hamburgu (tu w 1971 r. powstała „Fabrik”, zdaniem M. Gravari-Barbas najstarsza z „kulturalnych fabryk”, której program ogłaszany jest dziś obok

50 WARSTAATY Z GEOGPAFII TURYZMU 
programów miejskiego teatru i opery; grali tam m.in. B.B. King, Miles Davis i Nirwana), Londynie i Amsterdamie; nieco później trend ten dotarł także (między innymi) do Paryża (GRAVARI-BARBAS 2004). Także na lata 70. XX w. przypada okres zajmowania przez artystów nowojorskiego Soho.

Jednocześnie wprowadzanie funkcji kulturalnej na obszary poprzemysłowe przyjmowało także formy dużo bardziej zinstytucjonalizowane i sterowane odgórnie. Jak dowodzą cytowane przez KLIMEK (2010) badania przeprowadzone w 1987 r. w Wielkiej Brytanii, aż 32\% wszystkich nowych funkcji, jakie wprowadzano przy adaptacjach budynków poprzemysłowych w latach 80. XX w. w tym kraju było związane ze spędzaniem czasu wolnego i $z$ handlem ${ }^{1}$ (tendencja ta uległa zmianie w latach 90 ., kiedy $3 / 4$ nowych funkcji miało charakter mieszkaniowy i biurowy). Prekursorską rolę w tym zakresie w Wielkiej Brytanii odegrało Muzeum Nauki i Przemysłu w Manchesterze, zlokalizowane $\mathrm{w}$ dawnym dworcu kolejowym, będące kluczowym elementem dla rewitalizacji całej dzielnicy Castlefield (więcej na ten temat zob.: KACZMAREK 2001, DEREK 2010a, KLIMEK 2010). W tym, jak i w wielu innych podobnych przypadkach na wprowadzanie funkcji kulturalnej patrzy się bardzo szeroko: mogą one stać się impulsem dla rozwoju większego obszaru (kwartału, a nawet całej dzielnicy).

KLIMEK (2010, s. 245-246) wymienia kilka czynników, które wpływają na wybór programów kulturowych w przekształceniach dzielnic i zespołów poprzemysłowych:

- funkcje kulturowe są stosowane przez inwestorów jako narzędzie marketingowe, służące popularyzowaniu współczesnych przemian dawnych obszarów przemysłowych;

- realizacje prestiżowych budowli publicznych pozwalają na przełamanie niechęci do inwestowania na obszarach zdegradowanych, o negatywnym odbiorze społecznym i uruchomienia tzw. „efektu dźwigniowego";

- funkcje kulturowe moga przyczynić się do zwiększenia atrakcyjności dawnych miast przemysłowych jako środowiska pracy i zamieszkania;

- funkcje kulturowe (wraz z innymi funkcjami usługowymi: szkolnictwem wyższym, usługami komunikacji) mogą stać się podstawą gospodarki lokalnej.

\footnotetext{
${ }^{1} \mathrm{~W}$ kategorii tej wyodrębniono następujące podkategorie: rekreacja - 23 adaptacje $(5,75 \%$ wszystkich przekształceń obszarów poprzemysłowych), magazyny produktów spożywczych - 12 (3\%), kluby (12 $(3 \%)$, biblioteki $-10(2,5 \%)$, muzea $-10(2,5 \%)$, obiekty sportowe $-8(2 \%)$, hotele $-8(2 \%)$, bary, kawiarnie $6(1,5 \%)$, inne - 39 (9,75\%). Poza tym najczęściej do budynków poprzemysłowych wprowadzano przestrzenie pracy (178 adaptacji, 44,5\%); funkcje mieszkaniowe wprowadzono w 37 przypadkach (9,25\%); zaś 57 adaptacji $(14,25 \%)$ stanowiły programy wielofunkcyjne. Dane te, cytowane tu za KLIMEK (2010), pochodzą z publikacji URBED Re-using Redundant Biuldings. Case studies of Good Practise in Urban Regeneration, wydanej w Londynie w 1987 r.
} 
Ale oprócz działań kulturalnych, od których wszystko się zaczęło, na przestrzenie poprzemysłowe wprowadza się także inne funkcje związane z zagospodarowaniem czasu wolnego. Najbardziej spektakularnym (bo zrealizowanym na gigantyczną wręcz skalę) przykładem jest tu dolina rzeki Emscher w Zagłębiu Ruhry, gdzie na terenach poprzemysłowych powstały muzea, lodowisko, baseny, zbiornik do nurkowania, ścianki wspinaczkowe, sale koncertowe i widowiskowe, galerie, restauracje, a także mnóstwo innych obiektów rekreacyjnych, sportowych i kulturalnych (więcej na ten temat zob. np. DEREK 2010a). Innych, choć mniejszych adaptacji obszarów uprzednio użytkowanych, zdegradowanych, na cele związane ze spędzaniem czasu wolnego można by podawać bez liku. Są to czasem przedsięwzięcia prywatnych inwestorów, którzy licząc na zainteresowanie oryginalnym, postindustrialnym wystrojem lokują tu kluby czy restauracje; ale są to także inicjatywy i działania samorządowe (władz regionu, miasta, dzielnicy) bądź nawet rządowe (ta sytuacja jest charakterystyczna dla Wielkiej Brytanii), często z wykorzystaniem instrumentów partnerstwa publiczno-prywatnego. Należy sobie przy tym postawić pytanie: dlaczego akurat funkcje związane z czasem wolnym zasługują na szczególną uwagę przy przekształceniach terenów poprzemysłowych? Wydaje się, że można tu wysunąć kilka argumentów.

Po pierwsze, $\mathrm{w}$ centrach dużych miast często nie ma wolnych terenów na lokalizowanie funkcji związanych z czasem wolnym. Obszary poprzemysłowe są niejednokrotnie jedynymi wolnymi terenami, na które można takie funkcje wprowadzić. Przypadek ten w mniejszym stopniu dotyczy Polski (nawet w Warszawie $\mathrm{w}$ centrum miasta są jeszcze przestrzenie niezagospodarowane), ale występuje w bardzo wielu miastach zachodnioeuropejskich.

Po drugie, mieszkańcy miast przejawiają duże zapotrzebowanie na usługi i urządzenia związane $\mathrm{z}$ zagospodarowaniem czasu wolnego. Popyt na przestrzeń związaną z rozrywka, kulturą czy rekreacją jest ogromny i to nie tylko ze strony wykształconej klasy metropolitalnej (JAŁOWIECKI 2005), ale także ze strony "zwykłych" mieszkańców miasta, również tych mniej wykształconych i mniej zarabiających. Ten rosnący i (co nie mniej ważne) zmieniający się popyt potrzebuje nowych, wolnych przestrzeni, a ustępujący przemysł, idąc jakby „,z duchem czasu”, zwraca tereny, które do tej pory zajmował, umożliwiając zagospodarowanie ich na nowe potrzeby mieszkańców. A - jak wspomniano wyżej - w Europie Zachodniej są to nierzadko jedyne tak duże wolne tereny, położone relatywnie blisko centrum miasta.

Po trzecie, te częstokroć zdegradowane obszary po prostu nadają się na działalność związaną ze sztuką czy kulturą. Moda na postindustrialne wnęt- 
rza sprawia, że aby otworzyć $\mathrm{w}$ takim miejscu klub, teatr, galerię sztuki, a nawet restaurację, nie trzeba $\mathrm{w}$ nie dużo inwestować (a $\mathrm{z}$ pewnością bez porównania mniej niż przy adaptacjach takich budynków na cele mieszkaniowe czy biurowe). Artyści chętnie zgadzają się na gorsze warunki bytowe nie tylko ze względu na niższe czynsze (przy jednocześnie dużych przestrzeniach), ale także na duże pole do własnego działania oraz oryginalny „klimat" czy atmosferę miejsca.

Po czwarte, fakt, iż usługi związane z czasem wolnym w dużej mierze służą okolicznym mieszkańcom sprawia, że poprawiają jakość życia na danym obszarze. Wprowadzanie na obszary poprzemysłowe funkcji mieszkaniowych czy biurowych wiąże się z pojawianiem się nowych mieszkańców lub pracowników, i często z dość kontrowersyjnym (zwłaszcza z punktu widzenia lokalnej społeczności) procesem gentryfikacji tych terenów. Oczywiście, że otwarcie barów, klubów czy muzeów może wiązać się także z wizytami osób przyjezdnych (mieszkańców innych części miasta, turystów), jednak obiekty te są otwarte dla wszystkich - także dla lokalnych mieszkańców, nierzadko poprawiając poziom życia na danym obszarze.

Po piąte wreszcie, obszary poprzemysłowe są często nieodłącznym elementem tożsamości miasta lub jego fragmentu. Miejscowa ludność ma do nich sentyment, gdyż były tam "od zawsze", częstokroć stanowiły miejsce pracy dla niej lub jej krewnych czy przyjaciół. Wobec sentymentu i nostalgii, jaki mieszkańcy przejawiają względem tych immanentnych $w$ ich opinii dla miasta obszarów, zachowanie ich w formie otwartej dla nich samych może być ważne. Umożliwia się im $\mathrm{w}$ ten sposób spędzanie swojego czasu wolnego w miejscach będących częścią ich dziedzictwa, bo - jak trafnie zauważa DOERING (2003) - dla społeczności lokalnych na obszarach poprzemysłowych dziedzictwem są właśnie budynki przemysłowe, pozostałości, pamiątki, a także tradycje i dobrobyt lokalny; i to właśnie tak rozumiane dziedzictwo chcą oni chronić.

\section{...na warszawskiej Pradze}

Warszawa była przez dziesięciolecia ważnym ośrodkiem przemysłowym kraju². M. Krasucki, inwentaryzując warszawskie dziedzictwo poprzemy-

\footnotetext{
2 Jak podaje S. Misztal (1998, cyt. za: GolBA 2011), w 1985 r. przemysł zajmował w stolicy ok. 2300 ha, z czego 85\% wszystkich terenów przemysłowych skoncentrowanych było w 16 tzw. strefach przemysłowych, utworzonych na mocy ówczesnych planów urbanistycznych.
} 
słowe, opisał 100 obiektów pochodzących z XIX i z pierwszej połowy XX w. (KRASUCKI 2009), oraz 40 obiektów powojennych (KRASUCKI 2010). Część z nich została już wyburzona, niektóre wciąż czekają na swoje "drugie życie", a inne zaadaptowano na nowe cele. Do najbardziej bodaj znanych przekształceń terenów poprzemysłowych na cele związane z wykorzystaniem czasu wolnego należy Muzeum Powstania Warszawskiego w dawnej elektrowni tramwajowej i Fabryka Koronek „Landaua” mieszcząca m.in. restauracje na Woli oraz Centrum Artystyczne „Fabryka Trzciny” w dawnej fabryce marmolady, a później „pepegów”, na Pradze Południe.

Jednym z obszarów, na którym skoncentrowana została spora część zakładów przemysłowych stolicy, jest fragment prawobrzeżnej Warszawy (wcześniej odrębne miasto) - Praga. W niniejszym tekście nazwa ta będzie utożsamiana z dwiema obecnymi dzielnicami administracyjnymi: Praga Północ i Praga Południe. Przyczynami, dla których lokalizowano na tym terenie fabryki, zamieniając Pragę przełomu wieków w miasto przemysłowe, były ważne połączenia transportowe (w II połowie XIX w. otwarto tu dwie linie kolejowe: Petersburską i Terespolską; obecność kolei do dziś jest ważną determinantą rozwoju przestrzennego na Pradze - zob. rys. 1), ale także niskie ceny gruntów i położenie poza centrum stolicy (przy jednoczesnej bliskości tegoż centrum). Obecnie na terenie tych dwóch warszawskich dzielnic znajduje się duża część obiektów poprzemysłowych miasta (inną taką dzielnicą jest Wola) - dość powiedzieć, że ze skatalogowanych przez KRASUCKIEGO (2009) 100 obiektów warszawskiego dziedzictwa przemysłowego powstałego do II wojny światowej prawie połowa znajduje się na Pradze (32 obiekty na Pradze Północ i 15 na Pradze Południe). W związku z tak dużą liczbą różnego rodzaju obiektów ich wykorzystanie jest przeróżne: od kontynuacji działalności przemysłowej (np. Fabryka Czekolady „Wedel” przy ul. Zamoyskiego), przez pozostawienie budynków w stanie nieużytku i (nierzadko) ruiny (np. Warszawski Młyn Parowy przy Objazdowej), po adaptacje na rozmaite cele: edukacyjne (np. Szkoła Wyższa Psychologii Społecznej zajmuje część dawnej fabryki aparatów pomiarowych w rejonie ulic Gocławskiej, Chodakowskiej i Kałuszyńskiej); biurowe (np. dawna Fabryka Maszyn Młyńskich przy ul. Kłopotowskiego); handlowe i magazynowe (np. dawna Huta Szkła Targówek przy Radzymińskiej) i inne. Funkcje związane z wykorzystaniem czasu wolnego zajmują na Pradze nieliczne obiekty poprzemysłowe, przy zachowaniu bardzo różnych form przekształceń. Wyraźnie zarysowują się jednak trzy ogólniejsze sposoby zagospodarowania:

1. Zagospodarowanie punktowe. Pierwszą tendencję nazwać można punktowym zajmowaniem przestrzeni. Nawiązuje ona do opisanego na wstępie 
modelu zajmowania zniszczonych terenów poprzemysłowych przez artystów. Nie jest to efekt żadnej zaplanowanej polityki - dzięki dostępności wolnych, nieużytkowanych już przestrzeni i niewysokim czynszom, a w dalszej kolejności także dzięki wytworzonemu „klimatowi” dzielnicy, rozmaite osoby zaczęły indywidualnie lokalizować na Pradze swoją działalność, stwarzając zainteresowanym możliwości zagospodarowania swego czasu wolnego. Były to działania oddolne, w wyniku których zajmowano pojedyncze lokale, często fragmenty większych zakładów. Trend ten objął nie tylko przestrzenie poprzemysłowe, ale także inne pustostany, jak np. dawne mieszkania $\mathrm{w}$ zniszczonych kamienicach (choć $\mathrm{w}$ tych akurat organizowano głównie pracownie artystyczne, które - jako obiekty nieotwarte na co dzień dla przechodniów - trudno potraktować jako przestrzeń czasu wolnego). Do takich inicjatyw można zaliczyć stopniowe zajmowanie budynków dawnych Składów Towarzystwa Akcyjnego Przechowania i Transportowania Mebli i Towarów A. Wróblewski i Spółka przy ul. Inżynierskiej 3 (zob. rys. $1^{3}$ ) przez różnego rodzaju podmioty artystyczne i rozrywkowe, które często bardzo trudno zakwalifikować jednoznacznie do jednej tylko kategorii, np. klubokawiarnię sprzedającą i wystawiającą zarazem komiksy (Komiks Studio 23); klub muzyczny dysponujący jednocześnie metalowym hangarem przekształconym na salę teatralno-kinową i zajmujący się m.in. organizacją spektakli teatralnych, lub galerię sztuki (Nizio Gallery). Innymi przykładami mogą być budynki po dawnej Fabryce Wyrobów Gumowych „Brage” przy ul. 11 listopada 22, wraz z zabudowaniami sąsiedzkimi, gdzie mieści się teatr offowy (Teatr Academia Romana Woźniaka), kilka klubów muzycznych (Skład Butelek, Saturator, Zwiąż mnie, Hydrozagadka) oraz hostel (Hostel „Fabryka”); dawna Mechaniczna Fabryka Obuwia „Polus” SA przy Lubelskiej 30/32, która z kolei stała się siedzibą dla działań i inicjatyw teatralnych (teatr Scena Lubelska, komuna//warszawa); czy też adaptacja hangaru na terenie dawnego lotniska Gocław przy ul. Wał Miedzeszyński 646 na dyskotekę (Explosion) i klub squasha (Aerosquash). Jak widać z przytoczonych przykładów, te oddolne działania zagospodarowywania zaniedbanych i zdegradowanych obszarów to przede wszystkim inicjatywy artystyczne lub rozrywkowe (kluby, teatry, galerie), które nie wymagają wysokich inwestycji w zajmowaną zabudowę i zadowalają się zagospodarowaniem niewielkiej przestrzeni (najczęściej fragmentu większego kompleksu) na swoją działalność.

${ }^{3}$ Warto zwrócić uwagę, że obiekt ten, podobnie jak i kilka innych, o których będzie dalej mowa, nie jest już traktowany jako obiekt przemysłowy na mapach opracowanych przez Urząd Miasta Stołecznego Warszawa (stan na 2004 r.) - zob. rys. 1. 


\section{A - Praga Północ}

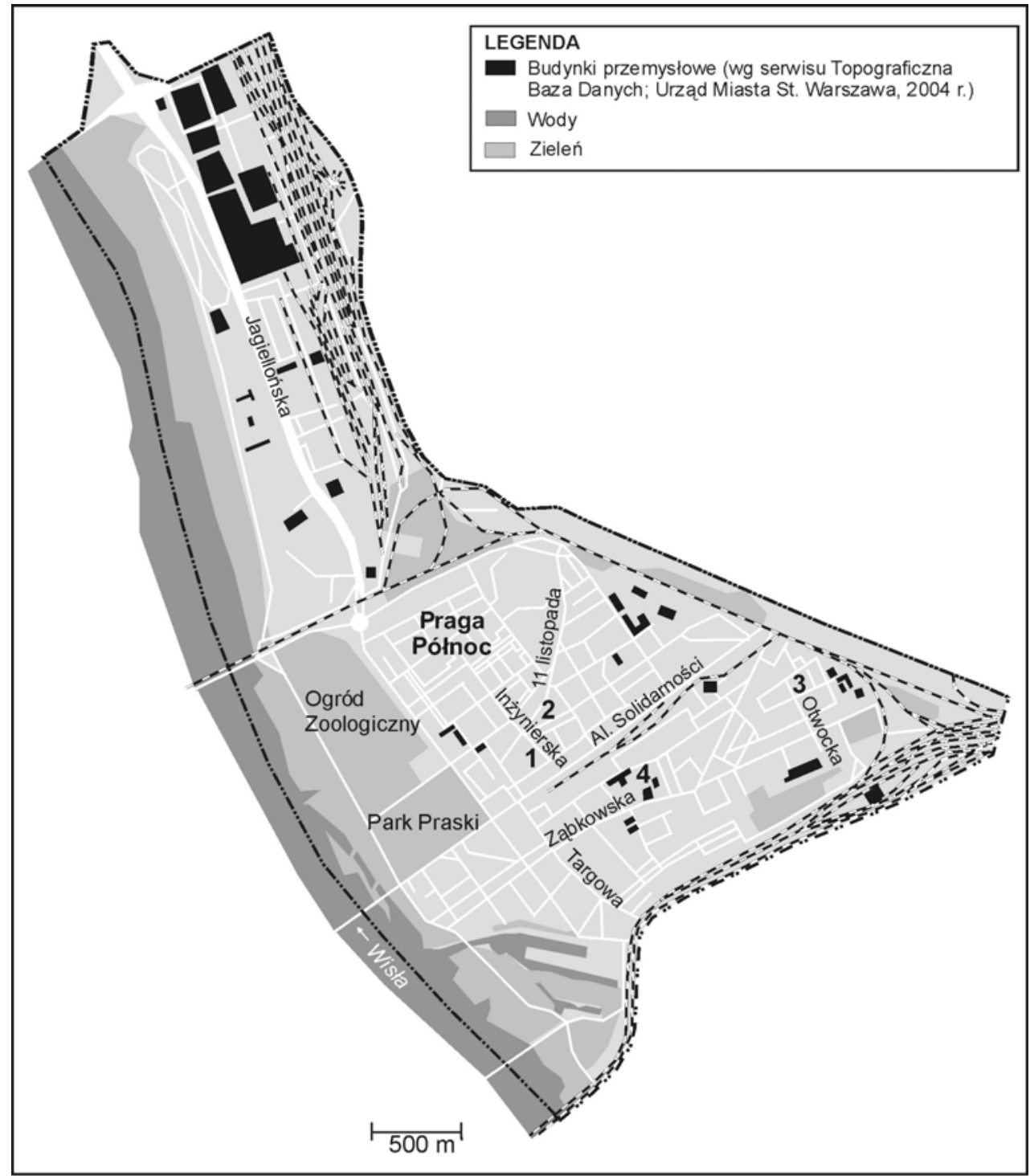




\section{B - Praga Południe}

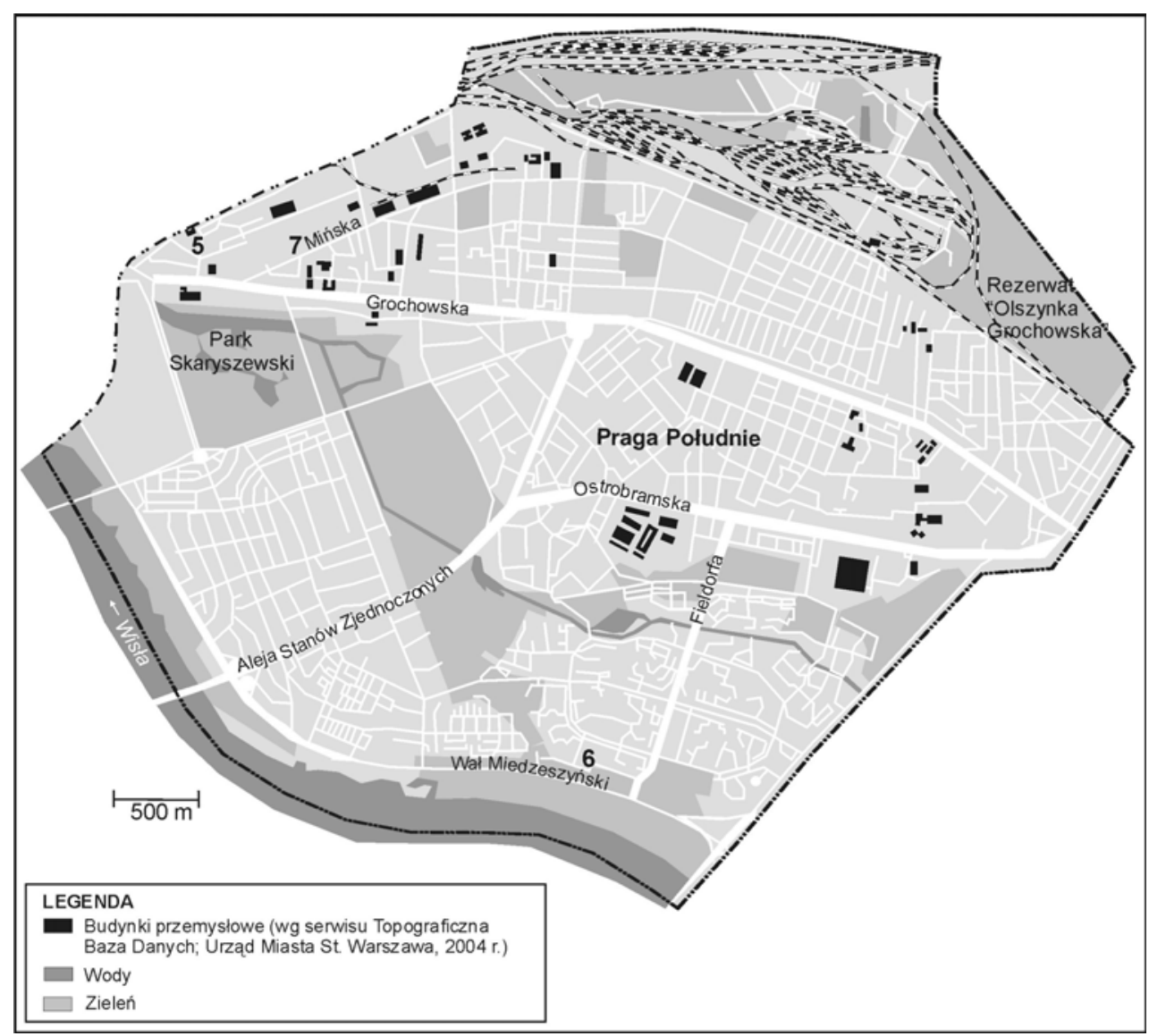

Rys. 1. Lokalizacja wybranych obiektów poprzemysłowych pełniących funkcje związane z czasem wolnym w warszawskich dzielnicach: Praga Północ (A) i Praga Południe (B)

1 - d. Składy Towarzystwa Akcyjnego Przechowania i Transportowania Mebli i Towarów A. Wróblewski i Spółka; 2 - d. Fabryka Wyrobów Gumowych „Brage”; 3 - d. Fabryka Polskiego Przemysłu Gumowego "Pepege”; 4 - d. Warszawska Wytwórnia Wódek „Koneser"; 5 - d. Mechaniczna Fabryka Obuwia „Polus" S.A.; 6 - Hangar na terenie dawnego lotniska Gocław; 7 - d. Warszawska Fabryka Motocykli Źródło: opracowanie własne na podkładach www.google.maps.pl oraz serwisu Topograficzna Baza Danych Urzędu Miasta Stołecznego Warszawa (http://www.mapa.um.warszawa.pl)

2. Zagospodarowanie obszarowe (kompleksowe). Inny model zagospodarowania przestrzeni poprzemysłowych opiera się na zagospodarowywaniu całych kompleksów (najczęściej dawnych zakładów przemysłowych). Moż- 
na tu wyróżnić dwa sposoby zagospodarowania: stworzenie przestrzeni czasu wolnego na terenie całego kompleksu poprzemysłowego bądź wprowadzenie funkcji związanych $\mathrm{z}$ czasem wolnym jako uzupełnienie innych funkcji (np. mieszkaniowych czy biurowych).

Przykładem takich całościowych przekształceń na przestrzeń czasu wolnego jest Centrum Artystyczne Fabryka Trzciny, zlokalizowane w dawnej fabryce marmolady, a później Fabryce Polskiego Przemysłu Gumowego „PePeGe” (ul. Otwocka 14). Teren ten wykupiła prywatna osoba, która postanowiła przekształcić go w swoisty dom kultury: mieści się tu teatr, galeria, restauracja, bary oraz sale klubowa i wystawowa. Miejsce to, otwarte w 2003 r. po dwuletnich pracach adaptacyjnych, stało się modne i znane w Warszawie już od początku swego istnienia.

Fabryka Trzciny zasługuje na uwage z wielu powodów, z których warto wymienić przede wszystkim dwa. Po pierwsze, była to pierwsza w Warszawie tak duża inwestycja $\mathrm{w}$ kulturę $\mathrm{z}$ wykorzystaniem przestrzeni poprzemysłowej. Po drugie, to całkowicie prywatna inicjatywa jednej osoby ${ }^{4}$, Wojciecha Trzcińskiego, który stworzył tu centrum kulturalno-rozrywkowe bez wsparcia bądź ingerencji władz miasta ani organizacji społecznych czy artystycznych, co było wówczas pionierskim działaniem. Warto pamiętać, że tego typu obiekty w Europie, wykorzystujące dawne fabryki do celów kulturalnych i artystycznych, są najczęściej inicjatywą albo grup i stowarzyszeń lokalnych lub artystycznych, albo władz miejskich.

Oczekiwano, że taki właśnie „europejski” los spotka dawny Monopol, czyli teren po Warszawskiej Wytwórni Wódek „Koneser” przy ul. Ząbkowskiej 27/31 (rys. 1), który miał się stać ważną przestrzenią czasu wolnego na Pradze. Jest to jeden z najbardziej rozpoznawalnych kompleksów architektury poprzemysłowej w Warszawie; jeden $\mathrm{z}$ nielicznych zachowanych $\mathrm{w}$ tej skali. Na kompleks o powierzchni ok. 5 ha składa się zespół zabytkowych budynków, z których 11 pochodzi z czasów budowy kompleksu (18951897). Są to m.in. portiernia $\mathrm{z}$ charakterystyczną bramą główny budynek produkcyjny, magazyn spirytusu, budynki mieszkalne i biurowe oraz in. (PILICH 2005, KRASUCKI 2009, www.rewitalizowane.fundacja-hereditas.pl). Na przełomie wieków XX i XXI próbowano zadłużający się coraz bardziej zakład restrukturyzować, a przy nowoczesnym cyklu produkcyjnym większa część zabudowań z XIX w. nie była potrzebna. Powstał więc pomysł, aby część kompleksu zrewitalizować i wykorzystać na cele kulturalne i tury-

${ }^{4}$ Jak opowiada na łamach prasy Wojciech Trzciński, adaptacji budynku dokonał nawet za własne pieniądze, gdyż „po wizycie na miejscu żaden bankier nie godził się na kredyt” (http://www.nieporecka. $\mathrm{pl} /$ Wall/images/stories/PulsBuzinesu.pdf). 
styczne; w celu koordynacji tych działań w roku 2001 powstało Stowarzyszenie „Monopol Warszawski”, a w 2004 Fundacja na Starej Pradze. Uruchomiono kilka projektów kulturalno-oświatowych; w 2005 r. powstał Teatr „Wytwórnia" ${ }^{5}$. Produkcji wódki zaprzestano rok później. W tym samym 2006 r. Ministerstwo Skarbu sprzedało „Konesera” Narodowemu Funduszowi Inwestycyjnemu „Piast” (obecnie BBI Development NFI SA) w wyniku przetargu. Wbrew wcześniejszym zapewnieniom władz miasta i nadziejom praskich stowarzyszeń, samorząd nie zdecydował się na zakup tego terenu i nie przystąpił do przetargu ${ }^{6}$. W 2007 r. władze podpisały porozumienie z deweloperem, na mocy którego 10\% zabudowy miało być wydzierżawione miastu i przeznaczone na działania i inicjatywy kulturalne, poza tym (oprócz mieszkań, biur, hotelu i pomieszczeń handlowych) miały tu powstać także restauracje oraz klub muzyczny (DĘBOWSKA 2007; www.koneser.eu). Całość miała być gotowa do 2012 r., choć termin ten z pewnością zostanie przesunięty.

W sierpniu 2011 r. na terenie „Konesera” znajdowały się m.in. dwa bary, tymczasowa sala ekspozycyjna Muzeum Warszawskiej Pragi (do czasu ukończenia budowy siedziby Muzeum przy ul. Targowej) i galerie artystyczne. Jest szansa, że powstanie tu Muzeum Designu, jako filia Muzeum Narodowego - 8 września $2011 \mathrm{r}$. został w tej sprawie podpisany list intencyjny przez wicedyrektor Muzeum Narodowego oraz wiceprezesa firmy BBI Development (URZYKOWSKI 2011). Na teren ten można było swobodnie wejść, a do wejścia zachęcała otwarta szeroko brama, bez strażnika, oraz stojące na ulicy ogłoszenia $\mathrm{z}$ informacją o cenach w ulokowanych tu lokalach gastronomicznych. Mimo wszystko trudno przewidywać, jak ta przestrzeń czasu wolnego będzie się przy ul. Ząbkowskiej rozwijała. Okolica ta - od lat uważana za "najgorszy" fragment starej Pragi - nie zmienia się zbyt dynamicznie. Oczywiście również dlatego, że wpływ władz miasta na przekształcenia tego terenu jest bardzo ograniczony. Choć trudno już teraz przesądzać, to jednak można obawiać się, że w przyszłości dla właściciela „Konesera” kultura będzie zaledwie przysłowiowym „kwiatkiem do kożucha” przy tej gigantycznej inwestycji. Wiele mówi fakt, iż z końcem 2010 r. przestał na terenie „Konesera” działać Teatr „Wytwórnia” (najstarsza kulturalna placówka tu funkcjonująca). Przestrzeń czasu wolnego (w tym wypadku kultura

\footnotetext{
${ }^{5} \mathrm{http}: / /$ www.ngp.pl/str/tekst1506.html (09.08.2011).

${ }^{6}$ Cytowana przez prasę wypowiedź ówczesnej prezydent Warszawy H. Gronkiewicz-Waltz: „Kupno Konesera było hasłem wyborczym Kazimierza Marcinkiewicza. Cena - około $57 \mathrm{mln}$ zł - była zbyt wygórowana. Ȧ̇ $54 \mathrm{mln}$ zł poszłyby na spłatę długu przedsiębiorstwa. Miasto nie może sobie pozwolić na nabywanie tak drogich nieruchomości. W dodatku o nie do końca wyjaśnionej sytuacji własnościowej" (cyt. za: DĘBOWSKA, URZYKOWSKI 2006).
} 
i gastronomia) jest w „Koneserze” funkcją uzupełniająca, dodatkowa, która ma poprawić wizerunek tego obszaru i prawdopodobnie podnieść ceny przyszłych mieszkań i biur.

O ile jednak w tym przypadku obszar „Konesera” został przez dewelopera niejako „zakupiony z artystami”, o tyle jeszcze bardziej skrajnym przypadkiem wykorzystania kultury i rozrywki do poprawy wizerunku obszaru są działania funduszu inwestycyjnego Black Lion na terenie Warszawskiej Fabryki Motocykli przy ul. Mińskiej $25^{7}$ (rys. 1) oraz sąsiednich Polskich Zakładów Optycznych przy ul. Grochowskiej. Postanowiono tu bowiem odgórnie pokierować procesem, który w wielu miejscach na świecie był spontaniczny i kończył się sukcesem: „To Rafał Bauer (pomysłodawca projektu i prezes Black Lion NFI - przyp. M.D.) zaprasza tu kolejnych najemców, kierując się własnym gustem, radami ludzi kultury i wizja że to miejsce ma tętnić życiem od rana do późnej nocy. Jego fundusz inwestycyjny pokrywa koszty rewitalizacji i remontu budynków, a najemcy płacą komercyjny czynsz." (KOWALSKA 2011). Do tych najemców w sierpniu 2011 r. należał klub M258, dwie galerie sztuki i restauracja - zaś wychodząc poza ramy przestrzeni czasu wolnego także (m.in.) redakcje, sklepy $z$ designem oraz pracownie projektowe i architektoniczne. Dodać należy, że zarówno galerie sztuki, jak i pracownie projektowe mające tu swe siedziby są to znane już na rynku instytucje, które stać na zapłacenie „czynszu komercyjnego". Poza tym znajdują się tu hale przeznaczone na wynajem dla różnego rodzaju imprez i wydarzeń; odbywały się tu m.in. koncerty Warszawskiej Jesieni, pokazy znanych polskich projektantów odzieży czy V edycja festiwalu „Rezydencja Twórczego Recyclingu Przetwory". Czym to miejsce w zamyśle jego twórców ma być oddaje też nadana mu nazwa: Soho Factory. Wszystkie te opisane wyżej działania mają służyć poprawie wizerunku obszaru, na terenie którego powstaną w dalszej kolejności biurowce i budynki mieszkalne. Prezes funduszu mówi o swoim pomyśle w ten sposób: „Mam oczywiście w tym pewien interes. Uważam, że każdy mecenat jakieś uzasadnienie mieć musi. [...] Moglibyśmy, mając tutaj plany mieszkaniowe, reklamować kolejną Cichą Przystań, Zieloną Zatoczkę. A doszliśmy do wniosku, że sensowniej byłoby wydać te pieniądze na stworzenie czegoś, co nas wtórnie będzie reklamować. I to jest powód naszego mecenatu. Uważam, że całkiem zboż-

\footnotetext{
${ }^{7}$ W końcu XIX w. obszar należał do Towarzystwa Akcyjnego Lnianej i Jutowej Manufaktury, następnie tereny te zostały przejęte przez Zakłady Amunicyjne „Pocisk”, a później Warszawską Fabrykę Motocykli. O 1965 r. właścicielem tego obszaru były Polskie Zakłady Optyczne (KRASUCKI 2010).

${ }^{8}$ Klub zajmuje modernistyczną kotłownię z końca lat 50. XX w. już od 2005 r.; jest bodaj jedyną działalnością związaną z wykorzystaniem czasu wolnego, jaka istniała na tym terenie zanim został on wykupiony przez fundusz Black Lion.
}

60 WARSZTATYZ GEOGRAFII TURYZMU 
ny. Dlatego, że jeżeli nam się ten cel ziści, to automatycznie jakość życia ludzi, którzy tu będą mieszkać się poprawi. A to będzie promieniowało na całą dzielnicę i ten kawałek miasta. Słowem - można zarabiać ładnie, średnio i nieładnie. Ja chciałbym ładnie." ${ }^{\prime 9}$

Inny dziennikarz stołecznej gazety zauważa jednak, że „na razie w praskim Soho króluje duch Pudełka, tutejsze imprezy przyciągają bowiem głównie celebrytów od Oliviera Janiaka po Patrycję Kazadi. Po świetnych akcjach artystyczno-społecznych, które organizowało w PZO stowarzyszenie „Artanimacje", zostały tylko Przetwory - festiwal recyklingu. Miejsce alternatywnej sztuki zajęły pokazy mody i zamknięte gale. To skutek polityki czynszowej - właściciel terenu wynajmuje hale po komercyjnych cenach, w związku z czym zamiast artystów sprowadzają się tu komercyjne galerie, firmy z branży medialnej i designerskiej." (PAWŁOWSKI 2011). Istotnie, przyznać należy, iż na terenie Soho Factory odbywa się wiele ekskluzywnych imprez, adresowanych nie tyle do artystów czy (tym bardziej) okolicznych mieszkańców, ale do bogatych przyjezdnych, jak np. prezentacja nowego modelu samochodu Range Rover w sierpniu 2011 r. Co więcej, cały teren jest ogrodzony i strzeżony, przez co wejść do niego można wyłącznie wówczas, gdy odbywa się tu jakaś impreza bądź w godzinach otwarcia instytucji tu funkcjonujących. Jak wynika z informacji uzyskanych od strażników, nie można tu też robić zdjęć. Jest to więc wybitnie komercyjna przestrzeń; może nawet nie tyle próba kolonizacji Pragi (PAWŁOWSKI 2011), co z pewnością rodzaj luksusowego getta ${ }^{10}$. Od nowojorskiego Soho różni ją bardzo wiele, choć należy przyznać, że taka inicjatywa być może pozwoli na zachowanie części przemysłowego dziedzictwa prawobrzeżnej części Warszawy. Pomimo kil$\mathrm{ku}$ drobnych inicjatyw nie jest to jednak tworzenie wysokiej jakości przestrzeni wolnego czasu w mieście, a raczej dość skrajny przykład wykorzystywania tego rodzaju przestrzeni jako narzędzia marketingowego. Doskonale ujmuje to K. Klunzmann (2004, s. 2, cyt. za: EvANS 2005), twierdząc, że: „każda historia dotycząca odnowy miejskiej zaczyna się od poezji, a kończy na deweloperach"11.

\footnotetext{
${ }^{9}$ Wywiad z Rafałem Bauerem przeprowadzony przez dziennikarkę „Gazety Wyborczej” Agnieszkę Kowalską, dostępny na jej blogu: http://zrobtowwawie.blox.pl/2011/04/Filozofia-Bauera.html (09.08.2011).

${ }^{10}$ Dość wspomnieć, że 6 grudnia 2010 r. odbył się tu koncert dla Prezydentów Polski i Rosji; więcej zob.: http://www.sohofactory.pl/content/wydarzenia (30.08.2011).

11 „Each story of regeneration begins with poetry and ends with real estate".
} 


\section{Pomysł na sukces}

Jak wspomniano już na początku niniejszego tekstu, w wielu miejscach na świecie spontaniczny proces zajmowania obiektów i obszarów poprzemysłowych przez funkcje związane ze spędzaniem czasu wolnego (najczęściej działalność kulturalna, gastronomiczna i rozrywkowa) skutkował zmianami charakteru całych dzielnic. Na Pradze jest jednak nieco inaczej. Działający tu artyści i właściciele klubów narzekaja że zmiany w tej prawobrzeżnej części Warszawy zachodzą zbyt wolno, a część z nich, zniecierpliwiona, już zaczyna te "mityczne” dzielnice opuszczać. Zdarzają się nawet dość skrajne opinie: „Sformułowanie «Praga - dzielnica artystów» zawsze mnie bawiło. To jest tylko i wyłącznie PR. Nic więcej [...]. Słyszę to od lat, że już za chwilę, już za momencik. To bzdura. Wystarczy spojrzeć na Ząbkowską. To jest ulica artystów z galeriami, butikami i kawiarniami? Czy ze sklepami monopolowymi?" (wypowiedź Łukasza Drgasa, właściciela Magazynu Praga, sklepu z designem, który od 2006 r. do lata 2011 działał na terenie „Konesera”, zaś od 3 września 2011 r. zmienił siedzibę na SoHo Factory; cyt. za: KOWALSKA, URBANIAK 2011)12. Jednak ten PR Pragi i wytwarzany tu przez kilkanaście lat „klimat" postanowili wykorzystać deweloperzy, którzy coraz częściej, oprócz planów budowania wyłącznie mieszkań i biur, chcą uzupełniać swoje inwestycje o miejsca, w których ich użytkownicy mogą spędzać swój wolny czas, przy okazji poprawiając wizerunek inwestycji. FAINSTEIN i GLADSTONE (1999) nazywają to celowymi działaniami deweloperów wykorzystujących artystów do gentryfikacji obszarów, na terenie których chcą inwestować.

Aby odpowiedzieć na pytanie, czy obecne przekształcenia na terenach poprzemysłowych na warszawskiej Pradze są tytułowym sukcesem, należy ten sukces przede wszystkim zdefiniować. Według Słownika języka polskiego (www.sjp.pwn.pl), sukces to: „pomyślny wynik jakiegoś przedsięwzięcia, osiągnięcie zamierzonego celu"13. Przyjmując tę definicję, sukcesy na Pradze zależą od stawianych celów, a z kolei cele każdego przedsięwzięcia zależą od tego, kto je stawia. Można zatem postawić pytanie nie o to, "czy”, ale „czyj” sukces powinniśmy tu analizować.

Jeżeli celem adaptacji przestrzeni przemysłowych na przestrzeń czasu wolnego byłoby wywołanie znanego na świecie procesu zmiany charakteru

${ }^{12}$ Opinie w podobnym duchu wyrażali też inni badani na Pradze artyści i właściciele urządzeń gastronomicznych i rozrywkowych, choć należy przyznać, że równie dużo jest opinii innych, dużo bardziej pozytywnych; por. DEREK 2010b; zob. też: BENEDYKTYNOWICZ, KOWALSKI, WOŹNIAK 2009, CHEŁSTOWSKA 2009.

${ }^{13}$ Drugie znaczenie słowa „sukces” to „zdobycie sławy, majątku, wysokiej pozycji itp.”. 
dzielnicy i podnoszenia wartości gruntów, można by mówić o sukcesie dzielnicy (korzyści estetyczne, finansowe, prestiżowe, itp.). Jednak na Pradze, jak już wspominano, tak się nie dzieje, a jakiekolwiek zmiany zachodzą bardzo powoli. Przyczynom tego stanu rzeczy można by prawdopodobnie poświęcić odrębny tekst, jednak poza innymi uwarunkowaniami prawnymi, instytucjonalnymi i finansowymi wspomnieć można o kilku. W Warszawie tereny poprzemysłowe nie są centralnym problemem władz miejskich; nie są położone w ścisłym centrum miasta i nie stanowią dużej części zabudowy (w przeciwieństwie np. do wielu miast śląskich). Ponadto, w ogromnej większości miast Europy, a także Stanów Zjednoczonych, zagospodarowanie terenów poprzemysłowych jest konieczne ze względu na brak wolnych przestrzeni oraz chęci zapobiegania procesom rozlewania miasta, tymczasem w Warszawie nie dość, że wciąż są jeszcze wolne tereny do zagospodarowania $\mathrm{w}$ pobliżu centrum, to proces suburbanizacji nie jest nawet postrzegany negatywnie ${ }^{14}$. Podobnie jak w przypadku wielu innych miast polskich brak jest polityki planistycznej i woli politycznej do wykorzystywania obszarów zdegradowanych - można powiedzieć prowokacyjnie, że deweloperzy wolą budować na greenfields niż na brownfields, a - jak pokazują chociażby badania JAŁOWIECKIEGO i in. (2009) - to właśnie oni rządzą miastem. Ogromnym problemem (zwłaszcza na Pradze, która nie została zniszczona w czasie II wojny światowej) są też nieuregulowane kwestie własnościowe wielu obszarów i budynków, w tym tych zdegradowanych i poprzemysłowych, spowodowane tzw. dekretem Bieruta. Na końcu należy jednak dodać, że wiele zależy po prostu od priorytetów politycznych władz.

Nieco inaczej na sukces można by spojrzeć oczami mieszkańców - dla nich mogłoby nim być uzyskanie nowych, atrakcyjnych przestrzeni czasu wolnego. Dzieje się to jednak w znikomym stopniu, gdyż mieszkańcy Pragi rzadko korzystają z tej nowej oferty kulturalno-rozrywkowej. Nie chodzą oni do Fabryki Trzciny; trudno sobie wyobrazić, aby inaczej miało się stać w przypadku „Konesera” czy Soho Factory ${ }^{15}$.

Czy zatem sukces odniosą deweloperzy? Czy ich pomysł na pokierowanie procesem, który na całym świecie z powodzeniem przebiegał oddol-

14 Jak podaje KLIMEK (2010), w Anglii poszanowanie terenów otwartych i ich zachowanie na przyszłość połączone z ograniczaniem rozwoju terytorialnego miast, realizowane m.in. przez ponowne zagospodarowanie terenów uprzednio użytkowanych, jest podstawą polityki przestrzennej. W 2008 r. $75 \%$ zabudowy mieszkaniowej w Anglii powstało na terenach uprzednio użytkowanych (w 1997 r. było to $45 \%$; zaś na obszarze Wielkiego Londynu w latach 1993-1997 aż 85\%).

${ }^{15}$ W tym ostatnim przypadku niezwykle malowniczo ujął to PAWŁOWSKI (2011): „Już widzę, jak mieszkańcy Kamionka ustawiają się w kolejce na warsztaty modowe, na których można się dowiedzieć, czy na bal lepsze są dodatki ze złota, czy platyny oraz jak za pomocą szampana konserwować buty z końskiego zada". 
nie, zakończy się powodzeniem? Jeśli tak, to czy będzie to wyłącznie finansowy sukces inwestycyjny, czy może wpłynie on także pozytywnie na jakość przestrzeni (i to nie tylko przestrzeni wolnego czasu) w tej części miasta? Za wcześnie by odpowiadać na te pytania, jednak obserwacja procesów i zmian zachodzących na obszarach poprzemysłowych na Pradze będzie z pewnością bardzo ciekawa. Trudno jednak nie ulec wrażeniu, że kolejne szanse na stworzenie na dawnych terenach poprzemysłowych prawdziwej kulturalno-rozrywkowej, atrakcyjnej turystycznie przestrzeni, którą nazwalibyśmy tutaj przestrzenią czasu wolnego, są zaprzepaszczane.

W Polsce problem zagospodarowania obszarów poprzemysłowych jest bardzo aktualny, a zachodnie sukcesy wprowadzania na takie tereny funkcji czasu wolnego wyglądają bardzo zachęcająco. Trudno jednak oprzeć się wrażeniu, że na warszawskiej Pradze (i nie tylko) inwestycje w obszary poprzemysłowe wynikają z mody na taką architekturę, podczas gdy prawdziwe potrzeby i powody, dla których warto w te tereny inwestować, umykają uwadze władz miasta. GRAVARI-BARBAS (2004, s. 282-283) postawiła w swoim tekście o „kulturalnych fabrykach” hipotezę, że obiekty te moga być jednocześnie miejscem bogatych eksperymentów społecznych i kulturalnych oraz katalizatorami rozwoju miejskiego, jednak wyłącznie w przypadku, gdy spełnionych jest jednocześnie kilka warunków: jasna chęć władz miejskich do wpierania artystów działających na tych terenach; projekt artystyczny promieniujący jednocześnie na dzielnicę i na miasto; oraz zamiana tych miejsc $w$ miejsca dziedzictwa bądź uwzględnienie przy ich adaptacji zmiany $\mathrm{z}$ miejsc otwartych dla wszystkich $\mathrm{w}$ miejsca symboliczne i nacechowane. Jak dotąd żaden $\mathrm{z}$ tych warunków nie jest w praskich rozwiązaniach spełniany.

\section{BIBLIOGRAFIA}

BENEdyKTYNOWicz Z., KOWALSKI G., WoźNIAK R., 2009, Między Praga a Próżna - rozmowa o warszawskiej Pradze i artystach na Pradze, „Konteksty”, 1-2, s. 83-93.

CHeŁstowsKA A., 2009, Pożywna inność. Warszawska Praga i gra w polu sztuki, „Konteksty”, 1-2, 174-184

DEREK M., 2010a, Turystyka przemysłowa, [w:] A. Kowalczyk (red.), Turystyka zrównoważona, Wyd. Naukowe PWN, Warszawa, s. 188-208.

DereK M., 2010b, Warszawska Praga jako miejska przestrzeń eksploracji turystycznej, „Turystyka i Hotelarstwo", 16, s. 9-30.

DęBOWSKA A.S., URZYKOWSKI T., 2006, Piast wchodzi do Konesera, „Gazeta Wyborcza” z 19.12. 2011, http://warszawa.gazeta.pl/warszawa/1,34861,3797029.html (09.08.2011).

DęBOWSKA A.S., 2007, W Koneserze już nie wódka, lecz kultura i mieszkania, "Gazeta Wyborcza” z 17.10.2007. 
Doering H., 2003, The New Face of Mining: Cultural Tourism and Identity in the Coalfield Areas. Developing Cultural Tourism, Conference Notthingham, 16 grudnia 2003 r., http://www. nottingham.ac.uk/ttri/pdf/conference/heike.pdf (19.12.2010).

Evans G., 2005, Measure for Measure: Evaluating the Evidence of Culture's Contribution to Regeneration, „Urban Studies”, 42, 5/6, s. 959-983.

FAINSTEIN S., GLADSTONE D., 1999, Evaluating Urban Tourism, [w:] D.R. Judd, S.S. Fainstein (red.), The Tourist City, Wyd. Yale University Press, New Haven, Londyn, s. 21-34.

GolBA A., 2011, Obszary poprzemystowe w Warszawie w okresie transformacji gospodarczej po roku 1989, mpis pracy magisterskiej, Wydział Geografii i Studiów Regionalnych, Uniwersytet Warszawski.

GRAVARI-BARBAS M., 2004, Les friches culturelles: jeu d'acteurs et inscription spatiale d'un "antiéquipement" culturel, [w:] C. Siino, F. Laumière, F. Leriche (red.), Métropolisation et grands équipements structurants, Presses Universitaires du Mirail, ser.: Villes et Territoires, s. 277230.

JAŁOWIECKI B., 2005, Przestrzeń ludyczna - nowe obszary metropolii, „Studia Regionalne i Lokalne", 3(21), s. 5-19.

JAŁOWIECKI B., SEKUŁA E. A., SMĘTKOWSKI M., TUCHOLSKA A., 2009, Warszawa. Czyje jest miasto?, Wyd. Scholar, Warszawa.

JANSEN-VERBEKE M., 1999, Industrial heritage: a nexus for sustainable tourism development, „Tourism Geographies”, 1, 1, 70-85.

KACZMAREK S., 2001, Rewitalizacja terenów poprzemystowych. Nowy wymiar w rozwoju miast, Rozprawy Habilitacyjne Uniwersytetu Łódzkiego, Łódź.

KLIMEK A., 2010, Problemy przekształceń zespołów zabudowy poprzemystowej w Wielkiej Brytanii, mpis rozprawy doktorskiej, Wydział Architektury Politechniki Warszawskiej, Warszawa.

KOWALSKA A., 2011, Kultura wśród fabryk. Powstaje warszawskie Soho, "Gazeta Wyborcza" z 30.04.2011, http://warszawa.gazeta.pl/warszawa/1,34889,9520048,Kultura_wsrod_fabryk_ Powstaje_warszawskie_Soho.html (10.05.2011).

KowalsKa A., UrbaniaK M., 2011, Praga. Dzielnica artystów czy slums Warszawy?, „Magazyn WAW" z 26.05.2011, http://magazynwaw.com/tekst/praga-dzielnica-artystow-czy-slumswarszawy/ (13.06.2011).

KRASUCKI M., 2009, Katalog warszawskiego dziedzictwa postindustrialnego, Wyd. Fundacja Hereditas, Warszawa.

KRASUCKI M., 2010, Katalog warszawskiego dziedzictwa postindustrialnego. Część II, Wyd. Fundacja Hereditas, Warszawa.

PAWŁOWSKI R., 2011, Duch Pudelka krąży nad Pragą. Kolonizacja dzielnicy, "Gazeta Wyborcza” z 02.05.2011, http://warszawa.gazeta.pl/warszawa/1,34861,9525787,_Duch_Pudelka _krazy_nad_Praga_Kolonizacja_dzielnicy_.html (10.05.2011).

PILICH M., 2005, Warszawska Praga. Przewodnik, Wyd. Fundacja „Centrum Europy”, Warszawa.

TOMAS F., 1982, Les friches industrielles et l'urbanisme en France, [w:] L'usine dans la ville, Revue de Géographie de Lyon, Université de Saint-Etienne, s. 13-20.

URRY J., 2007, Spojrzenie turysty, PWN, Warszawa.

URZYKOWSKI T., 2011, Muzeum designu w dawnej gorzelni na Pradze?, "Gazeta Wyborcza” z 09.09. 2011, (http://warszawa.gazeta.pl/warszawa/1,34889,10255198,Muzeum_designu_ w_dawnej_gorzelni_na_Pradze_html; 20.09.2011).

ZAŁUSKI D., 2005, Tendencje ksztattowania przestrzeni publicznych końca XX w., [w:] M. Kochanowski (red.), Przestrzeń publiczna miasta postindustrialnego, Biblioteka Urbanisty, Wyd. Urbanista, s. 55-84. 


\section{Źródła internetowe}

www.rewitalizowane.fundacja-hereditas.pl (25.01.2011).

http://www.ngp.pl/str/tekst1506.html (09.08.2011).

www.koneser.eu (30.08.2011).

http://www.nieporecka.pl/Wall/images/stories/PulsBuzinesu.pdf (01.09.2011).

http://www.sohofactory.pl/content/wydarzenia (30.08.2011).

http://zrobtowwawie.blox.pl/2011/04/Filozofia-Bauera.html (09.08.2011).

www.sjp.pwn.pl (01.09.2011).

http://www.archiwumetnograficzne.edu.pl/readarticle.php?article_id=60 (07.09.2011).

66 WARSZTATYZ GEOGRAFII TURYZMU 